\section{Heterogeneity of malaria prevalence in alluvial gold mining areas in Northern Mato Grosso State, Brazil}

\author{
Heterogeneidade da prevalência de malária em \\ garimpos do norte de Mato Grosso, Brasil
}

\author{
1 Centro de Desenvolvimento \\ e Planejamento Regional, \\ Universidade Federal de \\ Minas Gerais, Belo Horizonte, \\ Brasil. \\ Correspondence \\ A. F. Barbieri \\ Departamento de \\ Demografia, Centro \\ de Desenvolvimento e \\ Planejamento Regional, \\ Universidade Federal de \\ Minas Gerais. \\ Rua Curitiba 832, sala 806, \\ Belo Horizonte, $M G$ \\ 30170-120, Brasil. \\ barbieri@cedeplar.ufmg.br
}

\begin{abstract}
This paper analyzes factors affecting the risk of malaria among individuals working in wildcat gold mining camps (garimpos) in northern Mato Grosso State in the Brazilian Amazon. Historically, such mining camps have the locations with the highest malaria prevalence in the Brazilian Amazon. However, little attention has focused on understanding the disease from the internal perspective of the mining camps themselves, such as the mining population's characteristics and its spatial organization. This paper adopts a stepwise logistic model to identify spatial, occupational-exposure, and cultural factors that affect malaria prevalence. According to the results, differences among individuals working and/or living in the gold mining areas could produce different exposure to the disease and thus to different risk of malaria prevalence. Understanding these differences may provide an important tool for identifying risk profiles in the gold mining and related population and for informing programs for prevention and treatment of malaria in the Amazon.
\end{abstract}

Malaria; Occupational Exposure; Risk Factors
Alisson Flávio Barbieri 1

Diana Oya Sawyer 1

Historically, wildcat gold mining operations known as garimpos have been the locations with the highest malaria prevalence in the Brazilian Amazon. However, little attention has focused on understanding the disease from the internal perspective of mining camps themselves, namely the characteristics of the mining and related population and its spatial organization. Most studies on the relationship between population and the environment in the Brazilian Amazon have focused on the effects of population and agricultural land use on deforestation $1,2,3,4,5,6$, with less attention to the human health implications of different forms of land use such as agricultural settlement, cattle ranching, garimpos (small-scale, semi-mechanized, and highly labor-intensive mining of alluvial gold deposits), and urban-based activities. While previous studies in the Brazilian Amazon have shown an important association between high malaria prevalence, population characteristics, and land uses such as garimpos and new rural settlements, there is little causal evidence (backed by statistical models) to back such associations (some exceptions are Singer \& Sawyer 7; Castro 8; and Barbieri et al. 9).

This paper analyzes how malaria prevalence among individuals working and/or living in and around alluvial gold mining areas in northern Mato Grosso State in the Brazilian Amazon is related to distinct individual spatial, occupational-exposure, and cultural factors. The paper 
begins with a brief history of the settlement of northern Mato Grosso, particularly relating to the emergence of garimpos, and a brief overview of previous studies on malaria prevalence in alluvial gold mining camps in the Brazilian Amazon. We then describe the conceptual framework, data, measurement, and methods used in the analysis of how malaria prevalence in northern Mato Grosso is related to three sets of factors (spatial, occupation exposure, and cultural), followed by a discussion of the results and a brief conclusion.

\section{Alluvial gold mining and land settlement in northern Mato Grosso}

The Brazilian Mining Code of 1967 defines garimpo according to the following criteria: (i) precarious mining methods; (ii) mining in surface gold deposits; and (iii) individual, self-employed labor. Historically, the garimpo was the dominant locus of Brazil's gold production from the $17^{\text {th }}$ to the late 19th century, when it was gradually replaced by foreign capital-intensive mining operations 10 .

Since the 17th century, gold was known to exist in northern Mato Grosso State (located at $55^{\circ} 30^{\prime} \mathrm{W}-54^{\circ} 0^{\prime} \mathrm{W}$ and 9 $9^{\circ} 30^{\prime} \mathrm{S}-11^{\circ} 0^{\prime} \mathrm{S}$ ), in the Brazilian Amazon, but it was not until the early 20th century that the first wildcat pan-miners (garimpeiros) arrived by the Aripuanã and Juruena rivers 11. These pan miners and the indigenous population constituted the local population.

By the late 1960s there was a specific national policy regarding occupation of "empty" land in the country, mainly in the Amazon. This policy was implemented by opening new roads connecting the Amazon to the rest of Brazil, land settlement projects to attract the surplus population from the South and Northeast, and fiscal incentives to attract ranchers and entrepreneurs from the South. Construction of the Cuiabá-Santarém highway (BR-163) and a land settlement project in the early 1970s in northern Mato Grosso were part of this national policy. The first land settlement projects in northern Mato Grosso were designed to settle landless farmers from Southern Brazil and the State of Mato Grosso do Sul, but most of those who actually settled the region came there on their own, i.e., without any link to government or private land settlement schemes 12 . The expansion of agriculture and cattle ranching in northern Mato Grosso produced one of the highest deforestation rates in the Brazilian Amazon in the 1980s, continuing through the 1990s with the expansion of the so-called "soybean frontier" 9,13,14.
As a consequence of such land settlement, the population in the study area increased from approximately 100 individuals in the early 1970s to 23,000 in 1979, according to Mato Grosso Mining Company (METAMAT), a public foundation in charge of geological and mining research in Mato Grosso 15. Surface gold deposits were discovered in the area in 1979, attracting thousands of pan miners. As a result of gold's high price on the international market, Brazil's economic crisis, and the failure of land settlement projects due to a combination of inadequate soil, declining crop yields, and lack of infrastructure and markets for settlers, alluvial gold mining became the main economic activity in northern Mato Grosso in the 1980s 12,16. Such gold mining operations also fed the rapid urbanization rates in northern Mato Grosso, especially in the town of Peixoto de Azevedo, which became a key crossroads and lodging place for the flux of miners 12 .

This situation lasted for ten years, until the early 1990s. Newly elected President Collor de Mello's economic policy had several consequences for the garimpo boom, mainly a drop in the price of gold and an increase in the price of fuel (an essential input for alluvial mining). Additionally, by the late 1980s, the surface gold deposits had already dwindled to very low levels. Gold mining was forced to turn to deeper and deeper deposits and thus demanded more technology and capital. Traditional pan miners searched for new surface gold deposits in other areas and were replaced by newcomers with no experience in gold mining 17,18. Most of the latter were unemployed and/or unskilled workers from the country's poor Northeast. Although most of the local population involved in gold mining returned to their land 17, mining remained the economic mainstay for northern Mato Grosso, due to the direct effect of the mining or indirect effects of related activities. Gold mining was also responsible for the increase in the region's population, reaching some 216,000 by 199119 .

In the mid-1990s there were four major garimpo areas in northern Mato Grosso. The most important was Matupá (59\% of the gold mining population in northern Mato Grosso, according to METAMAT), located in the center and east of the study area. The Matupá area included the counties of Matupá, Peixoto de Azevedo, Terra Nova do Norte, and Guarantã do Norte. Alta Floresta ( $15 \%$ of the gold mining population in northern Mato Grosso) and Paranaíta (17\%) located in the western portion of the study area, include garimpos in the counties of Alta Floresta and Paranaíta, respectively. Finally, Teles Pires $(7 \%)$ included garimpos along the Teles Pires river, in the northwestern part of the study area. 


\section{Malaria prevalence in alluvial gold mining areas}

The technology used in the garimpos inevitably had a negative impact on the environment, directly linked to the high malaria prevalence in northern Mato Grosso. In the early 1990s, northern Mato Grosso had the highest malaria rate in Brazil, even surpassing other traditional endemic areas like Rondonia and southern Pará 9 .

The association between garimpos and endemic malaria has been observed elsewhere. Three main factors may account for this relationship. The first factor is the association between malaria prevalence and high mobility of infected miners 7,9,20,21,22,23,24. Accoding to Barbieri et al. $9,12,16$, the high malaria prevalence in northern Mato Grosso is largely explained by the high mobility of infected individuals between areas with high malaria prevalence (mining camps and new settlements) and others with low prevalence (urban areas and older settlements). Furthermore, the region from which the miners originally migrated and the duration of residence in the garimpo may also reflect different responses to malaria (cultural factors and biological resistance based on acquired immunity), as well as the ability, knowledge, and resources to avoid the disease 9 .

Second, high malaria prevalence is associated with lack of adequate health infrastructure and housing in the mining areas. Better housing (construction with durable walls, roofs, doors, and windows) impedes mosquito vector entry and thus intra-domiciliary infection. Lack of adequate health infrastructure (e.g., local health clinics) hinders diagnosis of the disease and isolation and medical treatment of symptomatic individuals.

Third, occupational characteristics of miners and the mining areas are also a key factor for high malaria prevalence. The high exposure of miners to the mosquito vectors in mining areas is linked to the proximity to the vector's natural habitat, particularly sources of still, shaded water and forests 8,25 . Links between malaria risk and the miners' occupational profiles are explained by the extremely long workday (12 to 24 hours, including the time of vector's most intense hematophagous activity) and limited protection against mosquitoes, and the predominance of unmarried, risk-prone young adult males 7,9.

Various other reasons are related to the miners' attitude towards the disease. They tend to display a kind of fatalism towards malaria, not amenable to any preventive measures, an unavoidable consequence of their daily life. The strong sense of individualism in these miners may also hinder forms of social interaction and the establishment of informal networks that might facilitate the exchange of information about malaria and potential sources of treatment.

\section{Conceptual framework}

Based on the above, we can define three sets of factors characterizing differential exposure to malaria among individuals involved directly in the alluvial gold mining as well as those affected indirectly (in trading, prostitution, transportation, etc.).

\section{Spatial factors}

Spatial factors related to the location of garimpo areas present varying potential for malaria prevalence. In particular, the relationship between the location of the mining area and the housing (inside the garimpo itself versus in a surrounding rural or urban area) can result in different degrees of exposure to the disease.

\section{Intensity of occupational exposure factors}

Population subgroups working directly or indirectly in the same garimpo area have different occupational and housing characteristics, which may cause varying exposure to the disease.

\section{Cultural factors}

Cultural factors have an impact on the capacity to prevent malaria and successfully treat those who have had past contact with endemic areas in their place of origin. Miners' with more schooling and stronger social networks are in a more favorable position for prevention and treatment.

\section{Data, measurement, and methods}

The data on gold miners in northern Mato Grosso were taken from a survey by the METAMAT in 1993. The sample includes 1,286 individuals directly or indirectly involving in the local gold mining camps. The dataset includes ten variables that were grouped according to factors defined in the conceptual framework.

The spatial factor refers to both the area where the actual mining is done and the miners' housing area (urban, rural, or inside the mining camp itself). Age group, gender, and marital status provided a proxy for intensity of occupational exposure factor. The rationale for this grouping was that in the garimpo, age, gender, and marital status are directly linked to the type of activity in 
which one is engaged, thus exposing individuals to malaria in varying degrees. The varying type of activity measures exposure more directly. Housing conditions are also an indicator of the degree of exposure.

The third factor consisted of three variables: schooling, place of birth, and social interaction. Place of birth was expected to indicate the type of socialization in different regions of Brazil, translated as specific cultural attitudes toward malaria, in turn causing different levels of exposure. For example, miners from the State of Maranhão (in the Northeast) have provided the traditional workforce for garimpos in the Amazon, while those from the South have a very recent history of gold mining in the same area. Social interaction indicates how socialization processes, i.e., how the individual interacts with the community (participation in parties, leisure activities, and meetings, and thus reliance on community members to mediate conflicts or disputes) can be an important instrument for establishing an informal network of information on health issues, including malaria prevention and health care.

A binary logistic model was used to assess the impact of these variables on malaria prevalence. Subjects were classified according to self-reported history of malaria in the three months prior to the survey. This self-reported malaria approach has been used in other studies in the Brazilian Amazon 7,9,23. The $\mathrm{Y}$ variable is a measure of malaria risk representing the two groups, thus $\mathrm{Y}=0$ when there was no history of malaria in the previous three months and $\mathrm{Y}=1$ if the individual reported malaria during the same period. The probability $\mathrm{p}$ of $\mathrm{Y}=1$ is obtained by fitting the model:

$\ln (\mathrm{p} / 1-\mathrm{p})=\beta \mathrm{X}$

where $: p$ is the probability of malaria prevalence; $\beta$ is the coefficient matrix of the model; $X$ is the covariant matrix.

The covariant $\mathrm{X}$ matrix consists of dummy variables elaborated from categories for the original variables, such that the category with theoretically lower risk (the reference category) was omitted from the model:

- Work region (omitted: REG4 = Teles Pires)

$\mathrm{X} 1$ = REG1: Alta Floresta;

X2 = REG2: Matupá;

X3 = REG3: Paranaíta.

- $\quad$ Place of residence (omitted: RES1 = urban):

$\mathrm{X} 4=\mathrm{RES} 2$ : garimpo;

X5 = RES3: both.

- Activity in the garimpo (omitted: ACT2 = prostitution):

X6 = ACT1: garimpo;

X7 = ACT3: indirect activities in garimpo.

- Age group (omitted: AGE3 = over 40 years of age):
X8 = AGE1: under 24 years of age;

X9 = AGE2: 25-39 years of age.

- Gender (omitted: SEX2 = female):

$\mathrm{X} 10=$ SEX1: male.

- Marital status (omitted: MAR2 = married):

X11 = MAR1: single;

X12 = MAR3: other marital status.

- Housing (omitted: HOS2 = makeshift housing):

$\mathrm{X} 13=\mathrm{HOS} 1$ : permanent housing.

- Place of birth (omitted: BRP3 = South/South-

east):

$\mathrm{X} 14=\mathrm{BRP} 1$ : Northeast;

X15 = BRP2: North and Central West.

- Schooling (omitted: EDU2 = some schooling):

X16 = EDU1: no schooling.

- Social interaction (omitted: SOC1 = high social interaction):

X17 = SOC2: low social interaction.

The $\beta$ coefficients were estimated by maximum likelihood and can be interpreted as the logarithm of the odds ratios between each category in the model and the category omitted from the original variable (ceteris paribus).

\section{Results and discussion}

Average malaria prevalence was $31.3 \%$. As explained above, this represents the mean proportion of subjects with at least one episode of the disease in the previous three months. Table 1 shows the frequency distribution of these variables. Most of the miners worked and lived directly in the garimpo in the Matupá region. The miners were predominantly single males 25 to 39 years old, originally from the Northeast of Brazil, and with no schooling and low social interaction in the mining camps. Despite this predominant pattern, they showed diversification in all the variables that might lead to differences in malaria prevalence.

Table 2 shows the models' parameter estimates and the statistical significance of each variable. The final model (Model 11) was obtained using a stepwise procedure; it excluded the gender and housing variables, because in step 6, the introduction of SEX1 (male) eliminated the significance of both variables representing the type of activity done in the garimpo, due to the high correlation between the two variables (thus the choice to exclude the gender variable from the model). The housing variable (HOS1) was not significant in steps 4 through 7 and was excluded from the subsequent steps.

The intercept represents subjects that are absent from the model, i.e., those working in the 
Characteristics of individuals working and/or living in alluvial gold mining areas (garimpos) in northern Mato Grosso State, Brazil.

\begin{tabular}{|c|c|c|c|}
\hline Factor & Variable & $\mathrm{n}$ & $\%$ \\
\hline \multirow[t]{9}{*}{ Spatial } & Region & & \\
\hline & Alta Floresta & 156 & 12.13 \\
\hline & Matupá & 801 & 62.29 \\
\hline & Paranaita & 250 & 19.44 \\
\hline & Teles Pires & 79 & 6.14 \\
\hline & Residence & & \\
\hline & Urban & 468 & 36.39 \\
\hline & Rural/Garimpo & 665 & 51.71 \\
\hline & Both & 153 & 11.90 \\
\hline \multirow[t]{18}{*}{ Intensity of occupational exposure } & Activity & & \\
\hline & Garimpo & 1,038 & 80.72 \\
\hline & Prostitution & 121 & 9.41 \\
\hline & Indirect & 127 & 9.87 \\
\hline & Age (years) & & \\
\hline & $<25$ & 294 & 22.86 \\
\hline & $25-39$ & 838 & 65.16 \\
\hline & $\geq 40$ & 154 & 11.98 \\
\hline & Gender & & \\
\hline & Male & 1,147 & 89.19 \\
\hline & Female & 139 & 10.81 \\
\hline & Marital status & & \\
\hline & Single & 754 & 58.63 \\
\hline & Married & 374 & 29.08 \\
\hline & Other & 158 & 12.29 \\
\hline & Housing & & \\
\hline & Permanent & 98 & 7.60 \\
\hline & Makeshift & 1,188 & 92.40 \\
\hline \multirow[t]{10}{*}{ Cultural } & Schooling & & \\
\hline & None & 867 & 67.42 \\
\hline & Some & 419 & 32.58 \\
\hline & Place of birth in Brazil & & \\
\hline & Northeast & 782 & 60.81 \\
\hline & North/Central West & 185 & 14.39 \\
\hline & South/Southeast & 319 & 24.80 \\
\hline & Social interaction & & \\
\hline & High & 193 & 15.01 \\
\hline & Low & 1,093 & 84.99 \\
\hline
\end{tabular}

Source: data elaborated from METAMAT 15.

Teles Pires region (REG4), living in the urban area (RES1), prostitutes (ACT2), married (MAR2), > 40 years of (AGE3), born in the South (BRP3), with schooling (EDU2), and with high social interaction (SOC1). The intercept coefficient was negative and significant at $1 \%$ in all steps, except when the variable "permanent housing" (HOS1) was introduced in step 4. In the final model (step 11), its value was -1.8315 , meaning that the "intercept group" had a prevalence of $13.81 \%$, which if compared with the mean prevalence of $31.3 \%$, shows this group's relative advantage in terms of lower malaria prevalence.

In the final model, REG2 (working in Matupá), RES3 (place of residence: urban/rural/garimpo), AGE1 (< 25 years), AGE2 (25-39), MAR3 (other marital status), and SOC2 (low social interaction) showed a positive and statistically significant as- 
Stepwise models and parameter estimates of probabilities of malaria infection in northern Mato Grosso State, Brazil.

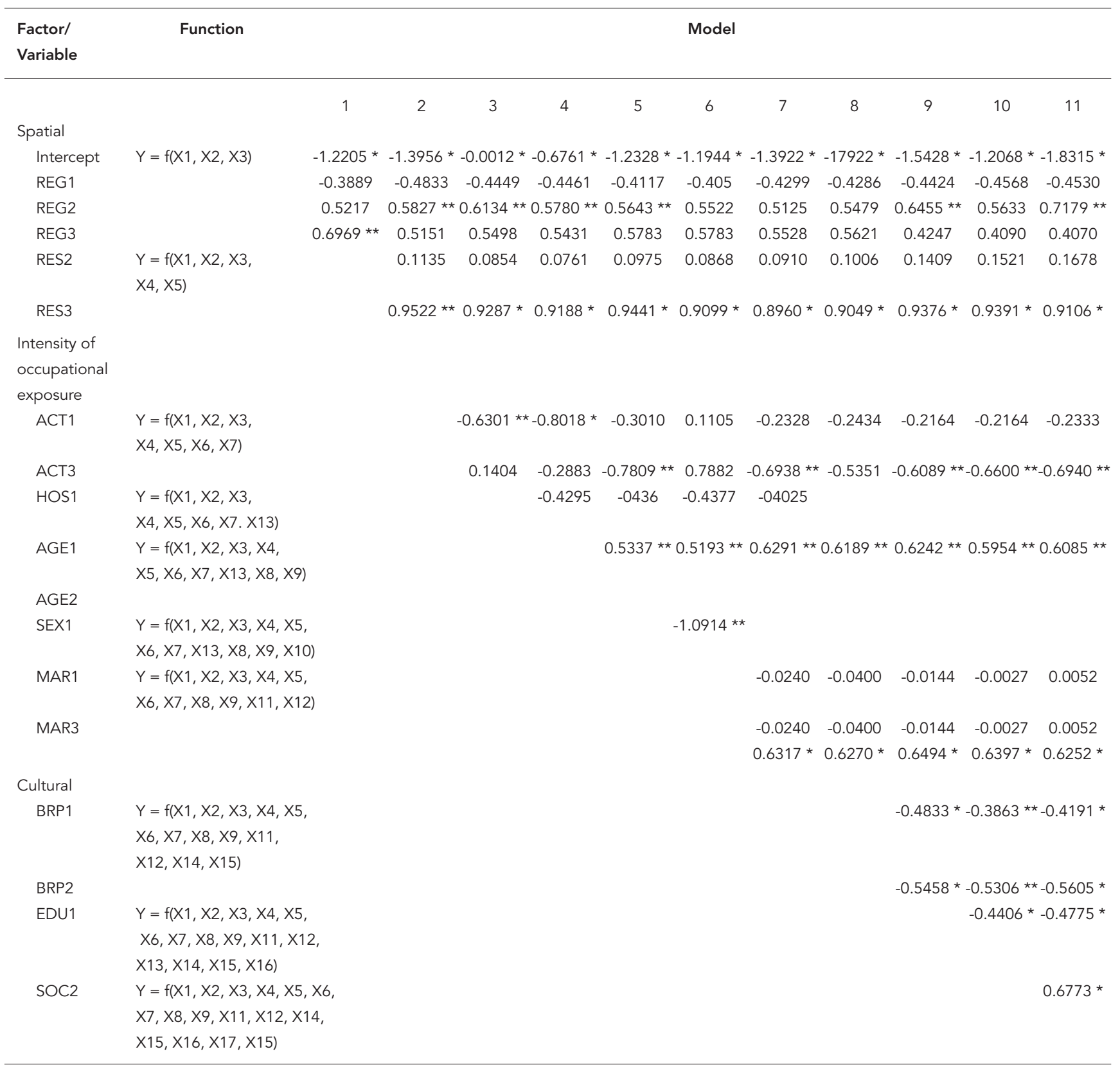

Source: data elaborated from METAMAT 26.

${ }^{\star} \mathrm{p}<1 \%$;

$\star \star 1 \%<p<5 \%$.

sociation with malaria prevalence. As expected, positively associated variables represented increased risk of malaria infection: the Matupá region includes the counties of Terra Nova, Nova Guarita, Peixoto de Azevedo, Matupã, and Guarantã do Norte, known to have the highest malaria prevalence in northern Mato Grosso and even
Brazil as a whole since the late 1980s 18. Even among miners themselves, those working in Matupá showed higher risk. Matupá may have other risk factors beyond individual traits (e.g., highly intense gold prospecting and/or a particularly hazardous environment). According to Model 11, miners living in both urban and rural/garimpo 
areas had higher prevalence than those living in urban areas, while those living exclusively in the garimpos showed no differences from those living in urban areas. This indicates that the degree of mobility may help explain the differences in prevalence, more than the garimpo environment itself.

The data also indicated that younger individuals and those with marital status other than single or married had more intense occupational exposure to malaria, and that those with low social interaction may have had less capacity to take preventive measures and obtain adequate treatment.

The variables ACT3 (indirect activities in the garimpo), BRP1 (born in the Northeast), BRP2 (born in the North and Central West), and EDU1 (no schooling) were significant and negative, showing less risk of infection than the intercept group. As expected, subjects involved in indirect activities like trade and transportation showed less risk of malaria than prostitutes, because they remained less time in the mining camps and at less risky times of the day. Subjects from the Northeast and North/Central West showed lower prevalence than those from the South/Southeast, possibly because the former have a long tradition of gold mining in the Amazon and have been exposed to many episodes of malaria. They are thus more prepared to deal with malaria and may be more resistant to the disease as compared to their counterparts from the South/Southeast. Surprisingly, those with no schooling showed lower prevalence, which could be explained by the lower overall schooling of individuals from the Northeast and North/Central West, who had lower prevalence rates.

Based on the above discussion, the apparently homogeneous gold mining population actually had many characteristics that posed differential risks of malaria. In addition, mining activity itself (ACT1) did not pose higher risk than prostitution, i.e., while the environment is highly hazardous, the risk is uneven among those working in the mining area. A hypothesis is that this result may also be related to the prostitutes' typically short- er period of residence in the garimpos and thus their limited ability, knowledge, or immunity to deal with the disease. However, all the other characteristics that were significant for explaining the differences referred mostly to the miners themselves, defining a sketchy profile of high malaria risk. As an example of the magnitude of this differential, the $\beta$ coefficient for RES3 (residence in urban and rural/garimpo areas) was 0.9106, meaning that the risk of contracting malaria was $28.48 \%$ and that this group's risk relative to the intercept group was 2.06. An example in the opposite direction was BRP2 (born in North/Central West), with an estimated $\beta$ coefficient of -0.5605 . The prevalence rate was $8.38 \%$, and the relative risk was 0.61 . Unfortunately, the sample size did not support a more complete model with interactions among variables, but the mere analysis of the main effects is sufficient to call attention to the heterogeneity of what was an apparently homogeneous population.

\section{Conclusion}

The results point to the possibility of understanding the characteristics of individuals working or living (or both) in alluvial gold mining areas in northern Mato Grosso that can increase malaria risk, rather than viewing the risk as affecting a purportedly homogeneous population. In fact, increased malaria risk in northern Mato Grosso can be understood as a function of: spatial factors related to the location of the mining areas and the place of residence of the individual at risk; intensity of occupational exposure factors related to female prostitution; younger age; and individuals "other" marital status; and cultural factors related to original areas of residence in South or Southeast Brazil, schooling, and lower social interaction. Understanding specific population dynamics associated with increased malaria risk may provide a powerful instrument for orienting malaria prevention, treatment and control policies in mining areas in the Amazon. 


\section{Resumo}

O artigo analisa fatores que afetam o risco de malária entre garimpeiros de ouro no norte de Mato Grosso, Brasil. Historicamente, os garimpos apresentam a maior prevalência de malária da Amazônia Legal brasileira. Entretanto, até o momento houve pouca investigação no sentido de compreender a doença desde a perspectiva interna dos próprios garimpos, ou seja, através das características da população garimpeira e da sua organização espacial. O artigo adota um modelo logístico stepwise para identificar fatores territoriais, culturais e de exposição ocupacional que afetam a prevalência da malária. Com base nos resultados, diferenças entre indivíduos que trabalham elou vivem nas áreas de garimpo poderiam produzir variações na exposição à doença, levando a um risco diferenciado de prevalência de malária. A compreensão dessas diferenças pode representar uma ferramenta importante para identificar perfis de risco na população do garimpo e do seu entorno, além de orientar programas para a prevenção e tratamento da malária na Amazônia.

Malária; Exposição Ocupacional; Fatores de Risco

\section{Contributors}

A. F. Barbieri worked in all phases of the article. D. O. Sawyer collaborated with A. F. Barbieri in the model specification, implementation, and analysis. Both authors reviewed a first draft and adjusted some issues to produce the final version submitted for publication.

\section{Acknowledgments}

The article draws on data from the project entitled Land Use and Health, conducted at the Centro de Desenvolvimento e Planejamento Regional, Universidade Federal de Minas Gerais [CEDEPLAR/UFMG; Center Regional Development and Planning, Federal University of Minas Gerais], in the 1990s, with support from the Rockefeller Foundation and International Development Research Center (IDRC).

\section{References}

1. Almeida AL. The colonization of the Amazon. Austin: University of Texas Press; 1992.

2. Caviglia, JL. Sustainable agriculture in Brazil: economic development and deforestation. Cheltenham: Edward Elgar; 1999.

3. Walker R, Moran E, Anselin L. Deforestation and cattle ranching in the Brazilian Amazon: external capital and household processes. World Development 2000; 28:683-99.

4. Perz SG. Household demographic factors as life cycle determinants of land use in the Amazon. Popul Res Policy Rev 2001; 20:159-86.

5. Walker R, Perz S, Caldas M, Silva, L. Land use and land cover change in forest frontiers: the role of household life cycles. Int Reg Sci Rev 2002; 25: 169-99.

6. Moran EF, Siqueira A, Brondizio E. Household demographic structure and its relationship to deforestation in the Amazon basin. In: Fox J, Rindfuss RR, Walsh SJ, Mishra, V, editors. People and the environment: approaches for linking household and community surveys to remote sensing and GIS. Boston: Kluwer Academic Publishers; 2006. p. 61-89.
7. Singer B, Sawyer DO. Perceived malaria illness reports in mobile populations. Health Policy Plan 1992; 7:40-5

8. Castro MC. Spatial configuration of malaria risk on the Amazon frontier: the hidden reality behind global analysis [Doctoral Dissertation]. Princeton: Princeton University; 2002.

9. Barbieri AF, Sawyer DO, Soares Filho BS. Population and land use effects on malaria prevalence in the Southern Brazilian Amazon. Human Ecol 2005; 33:847-74.

10. Salomão EP. A força do garimpo. Revista Brasileira de Tecnologia 1982; 13:13-20.

11. Departamento Nacional de Produção Mineral. Projeto monitoramento ambiental das áreas garimpadas na Amazônia brasileira. Brasília: Departamento Nacional de Produção Mineral; 1991.

12. Barbieri AF. Uso da terra e malária no norte do Estado de Mato Grosso, 1992-1995 [Masters Thesis]. Belo Horizonte: Departamento de Demografia, Universidade Federal de Minas Gerais; 2000.

13. Soares B. Modelagem da dinâmica de paisagem de uma região de fronteira de colonização Amazônica [Doctoral Dissertation]. São Paulo: Escola de Engenharia, Universidade de São Paulo; 1998. 
14. Nepstad DC, Carvalho G, Barros AC, Alencar A, Capobianco JP, Bishop J, et al. Road paving, fire regime feedbacks, and the future of Amazon forests. For Ecol Manage 2001; 5524:1-13.

15. Companhia Mato-Grossensse de Mineração. Diagnóstico das atividades mineradoras da Bacia do Rio Teles Pires. Cuiabá: Companhia Mato-Grossensse de Mineração; 1994.

16. Barbieri AF, Soares-Filho B, Coelho L. Uso da terra e malária: uma analise espacializada para o Norte de Mato Grosso, 1992 a 1995. In: Anais do XII Encontro da Associação Brasileira de Estudos Populacionais. Caxambu: Associação Brasileira de Estudos Populacionais; 2000. p. 1-22.

17. Centro de Desenvolvimento e Planejamento Regional. A research and education initiative on human health and effective utilization of tropical forests: narrative report. Belo Horizonte: Centro de Desenvolvimento e Planejamento Regional; 1994.

18. Sawyer DO, Dutra RD. O perfil das demandas pelos serviços de diagnóstico e tratamento da malária no norte de Mato Grosso. In: Anais do Seminário sobre Economia Mineira. Diamantina: Centro de Desenvolvimento e Planejamento Regional; 1995.

19. Departamento Nacional de Produção Mineral. Diagnóstico ambiental dos garimpos da Região Norte do Estado de Mato Grosso. Brasília: Departamento Nacional de Produção Mineral; 1994.
20. Castilla RF, Sawyer DO. Socioeconomic and environmental factors affecting malaria in an Amazon frontier area. In: Herrin AN, Rosenfield PL, editors. Economics, health and tropical disease. Manila: University of Philippines Press; 1986. p. 191-209.

21. Monte-Mór RLM. Malária e meio ambiente na Amazônia brasileira. In: Proceedings of the Latin American Seminar on Population and Health. v. 1. Campinas: Universidade Estadual de Campinas; 1986. p. 312-28.

22. Marques AM. Human migration and the spread of malaria in Brazil. Parasitol Today 1987; 3:166-70.

23. Spencer BR. Gold mining and malaria in the Brazilian Amazon [Masters Thesis]. New Haven: Department of Epidemiology, Yale University; 1996.

24. Sawyer DR. Deforestation and malaria on the Amazon frontier. In: Bilsborrow RE, Hogan D, editors. Population and deforestation in the humid tropics. Liège: Union Internationale pour l'Étude Scientifique de la Population; 1999. p. 268-91.

25. Marchesini PB, Spencer B, Lima MC. Distribuição espacial da malária no município de Machadinho/ RO, 1994. In: Anais do X Encontro da Associação Brasileira de Estudos Populacionais. Caxambú: Associação Brasileira de Estudos Populacionais; 1996. p. 2427-41.

26. Companhia Mato-Grossensse de Mineração. Diagnóstico das atividades mineradoras da bacia do Rio Teles Pires. Cuiabá: Companhia Mato-Grossensse de Mineração; 1993.

Submitted on 01/Aug/2006

Final version resubmitted on 28/Feb/2007

Approved on 19/Mar/2007 